\title{
HUMAS DALAM PERSPEKTIF ONTOLOGIS: TINJAUAN FUNGSIONAL MANAJEMEN HUMAS
}

\author{
Faiz
}

Univeristas Nurul Jadid, Probolinggo, Indonesia

faiz.s.fil.i@gmail.com

Didik Rahwiniyanto

Univeristas Nurul Jadid, Probolinggo, Indonesia

didik_smanjapaiton@yahoo.com

DOI: http:// doi.org/10.33650/al-tanzim.v3i2.651

Received: September $2019 \quad$ Revised: November 2019 Approved: Desember 2019

\begin{abstract}
:
This paper aims to examine the functional review of public relations management from an ontology perspective. Public Relations is an organizational activity that is manifested in the form of activities and at the same time is a process of communication between one individual with an individual or a community. The communication process that occurs and is created in this activity, is very important for the smooth and sustainable organization. Therefore, an ontology approach is needed, as part of a philosophical study to dissect about public relations management in terms of its function. As part of the study of philosophy, ontology has a very important role in finding out what and to what extent public relations management is to be achieved. In this perspective, the study of the functional review of public relations management concerns matters that have an existence in the dimensions of space and time, and can be reached by sensory experience, which includes the phenomenon of public relations that can be observed, measured and can be obtained and can be interpreted, so that it can be drawn a conclusion. This study uses a qualitative research type library approach. The data analysis technique used is content analysis. The results of the study show that; the managerial functional review of public relations covers the activities of fact finding, planning, communication, actuating, and evaluating.
\end{abstract}

Keywords: Management, Public Relations, and Ontology

Abstrak

Tulisan ini bertujuan untuk mengkaji tentang tinjauan fungsional manajemen hubungan masyarakat dalam perspektif ontologi. Humas merupakan aktivitas organisasi yang terwujud dalam bentuk kegiatan dan sekaligus merupakan proses komunikasi antara individu yang satu dengan individu atau suatu komunitas. Proses komunikasi yang terjadi dan tercipta dalam kegiatan ini, merupakan hal yang sangat penting bagi kelancaran dan keberlangsungan suatu organisasi. Oleh karena itu, diperlukan pendekatan ontologi, sebagai bagian dari kajian filsafat untuk membedah tentang manajemen humas ditinjau dari fungsinya. Sebagai bagian dari kajian filsafat, ontologi memiliki peran yang sangat penting dalam rangka menemukan tentang apa dan sampai di mana manajemen humas itu ingin dicapai. Dalam perspektif ini, kajian tentang tinjauan fungsional manajemen humas menyangkut hal-hal yang mempunyai eksistensi dalam dimensi ruang dan waktu, dan dapat dijangkau oleh pengalaman inderawi, yang meliputi fenomena tentang kehumasan yang dapat diobservasi, diukur dan dapat dioleh serta dapat diinterpretasikan, sehingga dapat ditarik suatu kesimpulan. Penelitian ini menggunakan pendekatan kualitif jenis library research. Tekhnik analisis data yang digunakan adalah content analisys. Hasil kajian menunjukkan bahwa; tinjauan fungsional manajerial humas meliputi 
Al-Tanzim : Jurnal Manajemen Pendidikan Islam

E-ISSN: 2549-5720 P-ISSN: 2549-3663

Vol. 03 No. 02 (2019) : 109-120

bttps:/ / ejournal.unija.ac.id/index.php/al-tanzim

kegiatan penemuan fakta (fact finding), perencanaan (planning), komunikasi/pelaksanaan (actuating), dan evaluasi (evaluating).

Kata Kunci : Manajemen, Humas, Ontologi

\section{PENDAHULUAN}

Setiap pengetahuan tidak bisa terlepas dari filsafat, karena filsafat adalah akar dari segala pengetahuan manusia baik pengetahuan ilmiah maupun non ilmiah. Hal-hal yang akan dibahas dalam tulisan ini adalah hubungan antara filsafat dengan ilmu manajemen humas atau public relations. Sekilas terlihat, tidak ada kaitan antara kedua ilmu tersebut, karena banyak orang berfikir bahwa filsafat itu bersifat abstrak dan bahasanya sulit dipahami; bahkan ada yang beranggapan bahwa filsafat hanyalah ilmu permainan kata. Sedangkan, ilmu manajemen merupakan ilmu yang konkret dan praktis. Namun, anggapan yang menyatakan bahwa tidak ada hubungan antara filsafat dan manajemen tidaklah benar. Filsafat dan manajemen ternyata memiliki kaitan yang erat, diantaranya adalah dengan manajemen hubungan masyarakat atau public relation (PR).

Peter Drucker sebagaimana dikutip oleh Ruslan (2008), seorang ahli bisnis dan professor terkemuka di bidang manajemen, berpendapat bahwa praktik dan ilmu manajemen memiliki dimensi filosofis yg sangat mendalam. Menurutnya, manajemen tidak bisa dilepaskan dari filsafat karena tanpa filsafat manajemen tidak memiliki pondasi yang kuat. Di sisi lain, tanpa manajemen filsafat akan menjadi hanya sebatas pengetahuan dan insight yang belum diterapkan ke dalam praktik.

Bagian dari filsafat yang berusaha menjawab pertanyaan mengenai hakikat ilmu disebut sebagai filsafat ilmu. Dalam filsafat ilmu manusia berfilsafat dalam rangka mendapatkan ilmu. Bukan sekedar mencari jawaban, tetapi juga mengajukan pertanyaan yang tepat. Filsafat ilmu berusaha untuk menjawab pertanyaan-pertanyaan mengenai: 1) obyek telaah suatu ilmu, 2) Wujud hakiki obyek tersebut, 3) hubungan antara obyek dan manusia yang membuah ilmu dan pengetahuan, 4) cara memperoleh dan mengembangkan ilmu pengetahuan yang benar dan 5) penggunaan ilmu dan pengetahuan (Aswad, 2012).

Untuk menjawab pertanyaan-pertanyaan yang berkaitan dengan hal di atas, ada 3 kajian dalam filsafat yang digunakan, yaitu kajian ontologi, epistemologi, dan aksiologi. Yang akan dibahas secara rinci dalam tulisan ini adalah kajian ontologi. Ontologi merupakan salah satu kajian kefilsafatan yang paling kuno yang berasal dari Yunani. Secara etimologi ontologi berarti ilmu yang mempelajari apa yang ada. Menurut Suriasumantri sebagaimana dikutip oleh Musyarrofah (2018), ontologi membahas tentang apa yang ingin kita ketahui, seberapa jauh kita ingin tahu, atau dengan kata lain suatu kajian mengenai teori tentang "ada". Telaah ontologis akan menjawab pertanyaanpertanyaan antara lain: 1) obyek ilmu yang akan ditelaah, 2) wujud yang hakiki 
Al-Tanzim : Jurnal Manajemen Pendidikan Islam E-ISSN: 2549-5720 P-ISSN: 2549-3663

Vol. 03 No. 02 (2019) : 109-120 https:// ejournal.unuja.ac.id/index.php/al-tanzim

dari obyek, dan 3) hubungan antara obyek tadi dengan daya tangkap manusia (seperti berpikir, merasa, dan mengindera) yang membuahkan pengetahuan.

Pengandaian ontologis dari praktik manajemen adalah hakekat dari praktik manajemen humas dalam lembaga pendidikan. Hakekat itu merupakan "ada"-nya dari manajemen humas. Inilah esensi dari praktik manajemen humas. Tanpa hakekat ini, praktik manajemen humas menjadi tidak bermakna. Ontologi dari manajemen humas adalah jaringan komunikasi intensif antar individu yang memiliki perbedaan keterampilan dan ilmu, namun bekerja untuk mewujudkan tujuan yang sama. Jaringan komunikasi itu tidak anonim, melainkan tertata dan mengarah pada tujuan yang jelas. Jaringan komunikasi itu juga mengandaikan adanya tanggung jawab masing-masing individu untuk berkomitmen pada tugas dan tujuan yang ada.

Seperti yang juga diingatkan oleh Drucker sebagaimana dikutip oleh Ruslan (2008), tujuan bersama tersebut haruslah terus diingatkan dan dipastikan kembali. Tujuan itu haruslah menjadi bagian dari identitas dan citacita bersama. Tanpa itu organisasi tidak lebih dari sebuah gerombolan. Jadi, ontologi dalam praktik manajemen humas merupakan komunikasi dan tanggung jawab individual yang saling terkait satu sama lain tanpa bisa terlepaskan

Hubungan masyarakat (humas) merupakan bentuk kegiatan dan sekaligus suatu proses komunikasi (Abrori, 2018). Proses komunikasi dalam kegiatan humas merupakan hal yang penting bagi kehidupan manusia. Sebab tanpa adanya komunikasi tidak mungkin akan terjadi interaksi. Pada umumnya humas merupakan suatu alat atau saluran untuk memperlancar jalannya interaksi dan penyebarluasan informasi (Mahfuzhah \& Anshari, 2018), melalui kerjasama antar pimpinan dengan pegawainya secara internal dan melakukan kerjasama dengan masyarakat ataupun khalayak ramai secara eksternal. Oleh karenanya perlu dikaji lebih lanjut tentang kerangka kerja manajemen humas dalam perspektif ontologis.

\section{Ontologi Ilmu Manajemen Humas}

Ilmu manajemen merupakan suatu kumpulan pengetahuan yang disistemisasi, dikumpulkan dan diterima kebenarannya. Hal ini dibuktikan dengan adanya metode ilmiah yang dapat digunakan dalam setiap penyelesaian masalah dalam manajemen (Usman, 2009). Metode ilmiah pada hakikatnya meliputi urutan kegiatan sebagai berikut: a) mengetahui adanya persoalan, b) mendefinisikan persoalan, c) mengumpulkan fakta, data dan informasi, d) menyusun alternatif penyelesaian, e) mengambil keputusan dengan memilih salah satu alternative penyelesaian, dan f) melaksanakan keputusan serta tindak lanjut. Selain manajemen sebagai ilmu, manajemen juga dianggap sebagai seni. Hal ini disebabkan oleh kepemimpinan memerlukan kharisma, stabilitas emosi, kewibawaan, kejujuran, kemampuan menjalin hubungan antara manusia yang semuanya itu banyak ditentukan oleh bakat 
seseorang dan tidak dapat dipelajari (Kasali, 2003).

Sebagaimana telah disinggung di awal, manajemen dapat diartikan sebagai proses. Menurut Sutikno (2012) menjelaskan bahwasannya proses yang dimaksud terdiri dari kegiatan-kegiatan fungsional manajemen, yaitu:

1. Perencanaan (Planning)

Perencanaan yaitu proses menetapkan sasaran dan tindakan yang perlu untuk mencapai sasaran. Dengan perencanaan berarti para manajer memikirkan kegiatan-kegiatan sebelum dilaksanakan. Berbagai kegiatan ini biasanya didasarkan pada berbagai metode, rencana atau logika, bukan hanya atas dasar dugaan atau firasat (Jefkins, 2003).

Morissan (2014) menyatakan bahwa perencanaan merupakan fungsi awal dari seluruh fungsi manajemen. Tanpa adanya perencanaan tidak dapat diketahui usaha yang dilakukan mencapai hasil atau tidak. Rencana strategis (strategic planing) merupakan rencana yang mencakup tujuan jangka panjang dan bersifat umum yang ingin dicapai organisasi. Berfikir strategis meliputi tindakan memperkirakan atau membangun tujuan masa depan yang diinginkan, menentukan kekuatan-kekuatan yang akan membantu atau akan menghalangi tercapainya tujuan, serta merumuskan rencana untuk mencapai keadaan yang diinginkan.

Ada empat langkah atau tahapan dasar perencanaan menurut (Rini, 2017), sebagai berikut; Pertama, menetapkan tujuan atau serangkaian tujuan. Perencanaan dimulai dengan keputusan-keputusan. Tanpa rumusan tujan yang jelas, sebuah lembaga akan menggunakan sumber daya-sumber daya yang secara tidak efektif. Kedua, merumuskan keadaan saat ini, pemahaman akan kondisi sekarang dari tujuan yang hendak dicapai sangat penting, karena tujuan dan rencana menyangkut waktu yang akan datang. Ketiga, Mengidentifikasikan segala kemudahan, kekuatan, kelemahan serta hambatan perlu diidentifikasikan untuk mengukur kemampuan dalam mencapai tujuan, oleh karena itu perlu dipahami faktor-faktor lingkungan internal dan eksternal yang dapat membantu mencapai tujuan, atau mungkin menimbulkan masalah. Keempat, mengembangkan rencana atau serangkaian kegiatan untuk mencapai tujuan tahap akhir dalam proses perencanaan meliputi pengembangan berbagai alternatif kegiatan untuk mencapai tujuan.

Lebih lanjut, Arikunto (2013) menyatakan bahwa perencanaan program humas tidak terlepas dari perencanaan program kerja secara keseluruhan, yang meliputi; identifikasi masalah, perumusan masalah, perumusan tujuan, analisis dan seleksi alternatif pemecahan masalah, identifikasi sumber penunjang/hambatan, untuk perumusan masalah, perumusan tujuan dan analisis seleksi alternative pemecahan masalah, 6) Penyusunan program, dan menyusun jadwal pertemuan dan kegiatan tahunan. 
Al-Tanzim : Jurnal Manajemen Pendidikan Islam E-ISSN: 2549-5720 P-ISSN: 2549-3663

Vol. 03 No. 02 (2019) : 109-120 https:// ejournal.unuja.ac.id/index.php/al-tanzim

Dalam penyusunan perencanaan program humas, harus terdapat hubungan erat antara tujuan program yang ditetapkan dengan sasaran yang dituju dan strategi yang dipilih (Jailani, 2018). Hal yang terpenting adalah bahwa strategi dipilih untuk mencapai suatu hasil yang dinyatakan dalam tujuan atau sasaran yang telah ditetapkan.

2. Pengorganisasian (Organizing)

Pengorganisasian yaitu proses mempekerjakan dua orang atau lebih untuk bekerjasama dalam cara terstruktur guna mencapai sasaran spesifik atau beberapa sasaran (Cangara, 2002). Dengan kata lain, pengorganisasian berarti para manajer mengkoordinasikan sumber daya manusia dan material organisasi. Kekuatan suatu organisasi terletak pada kemampuannya untuk menyusun berbagai sumber dayanya dalam mencapai tujuan. Semakin terkoordinasi dan terintegrasi kerja organisasi semakin efektif dan efisien (Mulyono, 2009).

Menurut Sagala (2000), pengorganisasian dapat diartikan sebagai kegiatan membagi tugas pada orang yang terlibat dalamkerjasama pendidikan. Kegiatan pengorganisasian tersebut dilaksanakan unuk menentukan siapa yang akan melaksanakan tugas sesuai prinsip pengorganisasian. Adapun prinsip-prinsip pengorganisasian meliputi: 1) memiliki tujuan yang jelas, 2) terdapat kesatuan arah sehingga dapat terwujud kesatuan tindakan dan pikiran, 3) terdapat keseimbangan antara wewenang dengan tanggungjawab, 4) terdapat pembagian tugas atau pekerjaan yang sesuai dengan kemampuan, keahlian dan bakat masingmasing, 5) bersifat relatif permanen, dan terstruktur sesederhana mungkin, sesuai kebutuhan, koordinasi, pengawasan dan pengendalian, 6) terdapat jaminan keamanan pada anggota, dan 7) adanya tanggung jawab serta tata kerja yang jelas dalam struktur organisasi.

Di samping itu, perlu adanya struktur organisasi yang merupakan cerminan semua pekerjaan yang dapat terbagi sesuai dengan kompetensi yang dimiliki dan dapat dikerjakan sesuai dengan keahlian masing-masing. Sebagaimana firman Allah SWT dalam QS. Al An'am ayat 132, sebagai berikut (Depag, 2000).

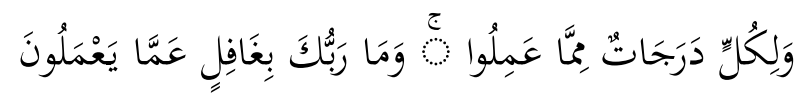

Artinya: Dan masing - masing orang memperoleh derajat-derajat (seimbang) dengan apa yang dikerjakannya. (QS. Al An'am: 132)

\section{Memimpin / Pengarahan (Leading / Directing / Actuating)}

Memimpin yaitu proses mengarahkan dan mempengaruhi aktivitas yang berkaitan dengan pekerjaan dari anggota kelompok atau seluruh organisasi (Soemirat, Soleh \& Ardianto, 2002). Dalam memimpin atau pengarahan berarti manajer mengarahkan, memimpin dan mempengaruhi 
para bawahan atau anggota. Manajer tidak melakukan semua kegiatan sendiri, tetapi menyelesaikan tugas-tugas essensial melalui orang lain. Mereka juga tidak sekadar memberikan perintah, tetapi menciptakan iklim yang dapat membantu para anggota melakukan pekerjaan secara paling baik.

Actuating artinya menggerakkan orang-orang agar mau bekerja dengan sendirinya atau dengan kesadaran secara bersama-sama untuk mencapai tujuan yang dikehendaki secara efektif. Kegiatan komunikasi sangat di butuhkan dalam pelaksanaan manajemen. Komunikasi dapat diartikan sebagai suatu proses penyampaian berita dari satu sumber berita kepada orang lain. Komunikasi merupakan segala bentuk perilaku seseorang baik verbal maupun nonverbal yang ditanggapi oleh orang lain. Berbagai jenis perilaku dapat dikatakan sebagai kegiatan komunikasi apabila melibatkan dua orang atau lebih. Komunikasi terjadi jika setidaknya suatu sumber membangkitkan respons pada penerima melalui penyampaian suatu pesan dalam bentuk tanda atau simbol, baik bentuk verbal (kata-kata) atau bentuk nonverbal (non kata-kata), tanpa harus memastikan terlebih dahulu bahwa kedua belah pihak yang berkomunikasi punya suatu simbol yang sama.

Komunikasi sebagai proses penyampaian berita dari seorang kepada orang lain itu sendiri melibatkan beberapa unsur yang alingberkaitan didalamnya. Di dalam kegiatan komunikasi terdapat berbagai unsur antara lain: a) sumber (source) atau sumber berita; merupakan tempat yang menunjuk pada asal diperolehnya suatu gagasan atau ide. Sumber ini harus jelas dan mudah dipahami, b) pengirim berita: pengirim pesan atau ide disebut sebagai komunikator atau coder, c) berita atau pesan (message), d) media atau saran penyampaian berita adalah benda yang digunakan untuk menyampaikan berita misalnya: surat kabar (untuk berita tertulis), bahasa bermakna, televisi (berita gambar dan suara), seorang penyanyi dan sebagainya., e) penerima berita (komunikan) adalah orang yang diberi berita atau orang yang menjadikan sasaran untuk dipengaruhi oleh pengirim berita, dan f) tujuan komunikasi. Seseorang yang mengirim berita tentunya memiliki tujuan untuk mempengaruhi penerima pesan atau berita tersebut (Kurnia, 2005)

4. Pengawasan / pengendalian (Controlling) dan Evaluasi (evaluating)

Pengendalian yaitu proses untuk memastikan bahwa aktivitas sebenarnya sesuai dengan aktivitas yang direncanakan (Saleh, 2008). Pengendalian/pengawasan berarti para manajer berupaya untuk menjamin bahwa organisasi bergerak kearah tujuan-tujuannya. Bila beberapa bagian organisasi berada pada jalur yang salah, manajer harus membetulkannya (Darmastuti, 2012). 
Al-Tanzim : Jurnal Manajemen Pendidikan Islam E-ISSN: 2549-5720 P-ISSN: 2549-3663

Vol. 03 No. 02 (2019) : 109-120 https:/ / journal.unuja.ac.id/index.php/al-tanzim

Evaluasi adalah tahap terakhir setelah tahap-tahap penelitian, perencanaan dan penggiatan yang dilaksanakan oleh suatu organisasi.39 Evaluasi dalam lembaga pendidikan memiliki peran penting yang berkaitan dengan perkembangan, kemajuan, atau kemunduran suatu program. Kegiatan evaluasi sangat strategis dalam upaya menentukan arah kebijakan selanjutnya bagi lembaga pendidikan. Evaluasi yang dilaksanakan akan berimplikasi pada kemajuan sekolah bila evaluasi dilakukan secara obyektif tanpa adanya intervensi dari sekolah terhadap opini publik dalam menentukan arah jawabannya akan suatu lembaga pendidikan yang ada di sekitarnya. Kemudian ditindak lanjuti dengan programprogram baru yang telah dimodifikasi sesuai dengan kebutuhan yang ada dalam program pelaksanaan evaluasi.

Pada dasarnya kegiatan evaluasi pelaksanaan program humas bertujuan untuk mengetahui implikasi suatu lembaga pendidikan terhadap masyarakat dalam berbagai hal. Sedangkan fungsi evaluasi dalam pelaksanaan humas yaitu; pertama, berfungsi selektif. Dengan adanya evaluasi, pihak sekolah memiliki cara untuk mengadakan seleksi terhadap kinerjanya. Kedua, berfungsi diagnostik. Bila menggunakan alat evaluasi yang memenuhi syarat, maka dengan melihat hasilnya sekolah bias mengetahui kelemahan yang dimilikinya. Ketika kelemahan telah teridentifikasi maka sekolah akan mudah mencari alternative dalam pemecahan masalah yang dialami melalui berbagai cara, tergantung tingkat kelemahan dan kebutuhan sekolah serta masyarakat. Ketiga, berfungsi sebagai pengukur keberhasilan. Untuk mengetahui sejauh mana suatu program berhasil diterapkan dan kemudian ditndaklanjuti dengan pengembangan program jika memungkinkan.

Atas dasar uraian tersebut, dapat diketahui bahwa kegiatan evaluasi dalam pelaksanaan program humas di lembaga pendidikan dilaksanakan untuk; 1) memperoleh informasi yang diperlukan untuk meningkatkan produktifitas serta keefektifan belajar siswa dan pengembangan sekolah, 2) memperoleh feed back, 3) memperoleh informasi yang diperlukan untuk memperbaiki dan menyempurnakan proses pembelajaran di sekolah, 4) memperoleh informasi yang diperlukan untuk memperbaiki, menyempurnakan serta mengembangkan program, 5) mengetahui kesukaran-kesukaran apa yang dialami siswa selama belajar dan bagaimana mencari jalan keluarnya.

Evaluasi pelaksanaan program humas dapat pula mengusulkan penambahan untuk peningkatan prestasi yang diharapkan dapat membawa ke arah perkembangan humas yang ada pada suatu lembaga pendidikan. Evaluasi dalam proses pengembangan dimaksud untuk memperbaiki sistem, pertanggung jawaban kepada pemerintah dan masyarakat, serta penentuan tindak lanjut hasil pengembangan, yaitu; pertama, perbaikan system. Peran evaluasi lebih bersifat konstruktif karena hasil penilaian 
dijadikan input bagi perbaikan yang diperlukan dalam program pelaksanaan humas di lembaga pendidikan yang sedang dikembangkan. Kedua, pertanggung jawaban kepada pemerntah dan masyarakat. Pada fase pelaksanaan perlu adanya pertanggung jawaban dari pelaksana kepada pihak yang berkepentingan.pihak-pihak yang dimaksud mencakup pemerintah, masyarakat, orangtua, petugaspetugas pendidikan, dan pihakpihak lain yang ikut mensponsori kegiatan pengembangan tersebut. Ketiga, penentuan tindak lanjut hasil pengembangan. Tindak lanjut yang dilakukan dapat berbentuk jawaban atas dua pertanyaan. Pertama, apakah sistem baru tersebut akan atau tidak akan disebar luaskan. Kedua, dalam kondisi bagaimana dan dengan cara yang bagaimana sistembaru itu akan disebarluaskan.

\section{METODE PENELITIAN}

Penelitian ini menggunakan pendekatan kualitatif jenis penelitian kepustakaan (library research). Dalam penelitian ini, peneliti berusaha untuk mengkaji tentang tentang tinjauan fungsional manajemen hubungan masyarakat dalam perspektif ontologi, dengan cara deskriptif-kritis dengan menekankan pada kekuatan analisis terhadap data dan sumber yang ada, dengan mengandalkan teori dan konsep yang ada, kemudian diinterpretasikan berdasarkan tulisan-tulisan yang mengarah kepada pembahasan. Tekhnik analisis datanya menggunakna content analysis, yaitu tekhnik yang digunakan oleh peneliti untuk menarik kesimpulan melalui usaha untuk menemukan karekteristik pesan yang disampaikan, dan dilakukan secara objektif dan sistematis.

\section{HASIL PENELITIAN DAN PEMBAHASAN}

\section{Tinjauan Fungsional Manajemen Humas dalam Perspektif Ontologis}

Kerangka kerja manajemen humas pada lembaga pendidikan adalah perencanaan dan manajemen untuk mencapai suatu tujuan. Dalam rangka mencapai suatu tujuan tersebut, kerangka kerja tidak hanya berfungsi sebagai peta jalan yang hanya menunjukkan arah saja, melainkan harus mampu menunjukkan bagaimana taktik operasionalnya (Anggoro, 2000).

Menurut Rachmadi (1996) kerangka kerja atau tinjauan fungsional manajerial humas meliputi kegiatan penemuan fakta (fact finding), perencanaan (planning), komunikasi/ pelaksanaan (actuating), dan evaluasi (evaluating). Adapun penjelasannya adalah sebagai berikut;

Pertama, reseacrh - penemuan fakta (fact finding). Penemuan fakta dilakukan untuk mengetahui bagaimana situasi dan kondisi yang terjadi di lapangan dan apakah situasi dan pendapat dalam masyarakat menunjang atau justru menghambat kegiatan organisasi. Dalam tahap penemuan fakta ini seorang petugas humas dituntut sebagai berikut; a) memperhatikan berbagai kejadian atau perkembangan sosial, politik maupun ekonomi yang secara 
Al-Tanzim : Jurnal Manajemen Pendidikan Islam E-ISSN: 2549-5720 P-ISSN: 2549-3663

Vol. 03 No. 02 (2019) : 109-120 https:// ejournal.unuja.ac.id/index.php/al-tanzim

langsung atau tidak langsung berhubungan dengan lembaga atau organisasi, b) mengumpulkan berbagai macam data untuk diolah menjadi informasi, c) menganalisis informasi itu agar sesuai dengan keperluan lembaga atau organisasi, d) selalu siap menyajikan berbagai informasi secukupnya kepada setiap unit organisasi, e) menyempurnakan segala macam informasi yang dirasakan masih kurang memadai, f) melengkapi simpanan data dan informasi antara lain dengan menyelenggarakan dokumentasi dan press clipping.

Sehubungan dengan kegiatan penemuan fakta ini, khususnya yang menyangkut opinion research, maka menemukan empat tahap penelitian yaitu: a) penelitian tentang situasi yang sedang terjadi (current situation), khususnya mengenai apa yang sedang dipikirkan orang dan mengapa, b) penelitian tentang prinsip-prinsip dasar humas yang sedang dilaksanakan oleh organisasi, c) penelitian tentang hasil, bagaimana orang memberikan reaksi terhadap protesting yang diadakan oleh organisasi, misalnya terhadap reaksi pendapat atas suatu iklan ataupun artikel khusus yang ditulis oleh bagian humas, d) mengadakan evaluasi mengenai bagaimana orang memberikan reaksi dan responnya terhadap stimuli lainnya yang diberikan oleh organisasi.

Kedua, perencanaan dan mengambil keputusan (planning - decision). Dalam tahap ini yang merupakan kelanjutan dari tahap penemuan fakta, seorang praktisi humas merencanakan bagaimana sebaiknya, dengan memperhatikan factor faktor psikologis, sosiologis, keadaan sosial, ekonomi dan politik. Pesan dari komunikator dirumuskan agar dapat mencapai tujuannya, dalam tahap ini sejumlah langkah yang perlu dilakukan, yaitu; merumuskan apa tujuan yang harus dicapai oleh humas ketika mengirim pesan tertentu, mengolah data yang diperolehnya tentang berbagai faktor yang diperlukan, merumuskan bagaimana pesan harus disebarkan, menentukan teknik komunikasinya, memeriksa kesempurnaan informasi yang diperolehnya pada tahap fact finding, membandingkan pengalaman-pengalaman pihak lain dan organisasinya sendiri guna memperoleh langkah terbaik, mengadakan analisis atas informasi yang diperoleh serta merumuskannya sesuai dengan program kerja, yaitu sesuai dengan situasi dan tempat (Haryanto and Rozza, 2012).

Perencanaan program kerja public relation (PR) mau tidak mau harus dikaitkan dengan cita-cita dan tujuan organisasi. Sehubungan dengan ini, terdapat dua program PR yang bersifat mendasar yaitu program PR yang bersifat preventif dan bersifat remedial. Program PR yang preventif adalah suatu program yang direncanakan untuk mencegah terjadinya hal-hal yang tidak diinginkan oleh organisasi, sedangkan program remedial sehubungan dengan perbaikan situasi dan kondisi yang terjadi pasca krisis.

Ketiga, komunikasi / pelaksanaan (actuating). Tahapan komunikasi adalah kelanjutan dari perencanaan tentang bagaimana mengkomunikasikan sesuatu dan apa yang dikomunikasikan, sebenarnya juga tidak terlepas dengan tujuan yang ingin dicapai melalui kegiatan humas. Kegiatan komunikasi dapat 
berbentuk isian, tertulis, visual, atau dengan menggunakan lambang-lambang tertentu (Ardhoyo, 2013).

Dalam organisasi, komunikasi merupakan media yang memiliki fungsi penghubung serta pembangkit motivasi antar setiap anggota sehingga sebuah organisasi dapat berjalan maju. Proses komunikasi yang efektif merupakan syarat terbinanya kerja sama yang baik untuk mencapai tujuan organisasi. Komunikasi dalam sebuah organisasi merupakan unsur pokok selain tujuan organisasi dan motivasi (Krisna Mulawarman, 2018).

Pemahaman tentang manajemen komunikasi wajib dimiliki oleh para manajer yang bertanggung-jawab atas aktivitas sebuah organisasi. Proses komunikasi terdiri dari dua ranah utama, yaitu ranah "manusia" yang menjelaskan situasi dan kondisi yang dimiliki manusia dalam berkomunikasi dengan kelebihan dan kelemahannya, dan ranah "kompetensi" yang menjelaskan pemahaman dan keterampilan dalam berkomunikasi. Bila ranah pertama adalah pemahaman, ranah kedua adalah bagian keterampilan atau kecakapan yang selalu dapat ditingkatkan dan diperbaharui. Artinya, kemampuan berkomunikasi tidak lahir dengan sendirinya, melainkan harus dipelajari dan ditingkatkan (Bakri Yusuf, 2018).

Sedangkan actuating merupakan tindakan mengupayakan seluruh anggota organisasi untuk mencapai tujuan sesuai dengan perencanaan yang sudah ditetapkan (Arumsari, 2017). Actuating atau tindakan yang dilakukan oleh seorang manager sebagai pengawalan terhadap perencanaan yang telah dibuat, harus berdasarkan pada hasil keputusan atau ketetapan bersama dengan tujuan untuk mencapai target yang telah ditentukan secara optimal. Penggerakan itu sangat diperlukan menggerakkan semua anggota kelompok untuk bekerja agar mencapai tujuan organisasi (Awaluddin, 2018).

Keempat, Evaluasi (Evaluation). Setelah komunikasi dilakukan maka suatu organisasi tentu ingin mengetahui dampak atau pengaruhnya terhadap publik atau khalayak. Menurut Grunig \& Hunt dalam (Putra, 1999), tahaptahap yang perlu dilakukan untuk mengevaluasi; 1) Buat rumusan tujuan program yang spesifik dan dapat diukur (specity objectives), 2) Pengukuran efek yang sudah dicapai dari program yang dijalankan (measures the objectives), 3) Pengumpulan data dan mengukur efek pada sample terpilih, 4) Buat laporan tentang hasil program kepada pengambil keputusan (manajemen). Setiap hasil program harus diterapkan pada pengambilan keputusan (hasil yang dicapai untuk memperbaiki program selanjutnya.

Di lain pihak, Morisan (2008) menyatakan bahwasannya langkahlangkah evaluasi program humas dapat dilakukan dengan tiga tahap sebagai berikut; 1) Evaluasi tahap persiapan memberikan penilaian atas kualitas informasi dan kecukupan informasi serta perencanaan yang telah dilakukan, 2) evaluasi tahap pelaksanaan menilai kelengkapan taktik dan cukupan usaha yang telah dilakukan, evaluasi terhadap dampak memberikan penilaian atas efek yang dihasilkan dari suatu program kehumasan yang telah dilaksanakan. 
Al-Tanzim : Jurnal Manajemen Pendidikan Islam

E-ISSN: 2549-5720 P-ISSN: 2549-3663

Vol. 03 No. 02 (2019) : 109-120

https:// ejournal.unuja.ac.id/index.php/al-tanzim

\section{KESIMPULAN}

Manajemen hubungan masyarakat adalah suatu komunikasi (penyampaian informasi) yang dilakukan melalui tahap penelitian, perencanaan, pelaksanaan, dan pengevaluasian oleh lembaga atau organisasi terhadap masyarakat. Manajemen humas merupakan bentuk komunikasi timbal balik yangdilakukan dengan dua arah antara organisasi dengan masyarakat dengan tujuan untuk mewujudkan fungsi dan tujuan manajemen melalui peningkatan kerja sama, serta memperhatikan kepentingan bersama. Tinjauan fungsional manajerial humas meliputi kegiatan penemuan fakta (fact finding), perencanaan (planning), komunikasi/ pelaksanaan (actuating), dan evaluasi (evaluating).

\section{DAFTAR PUSTAKA}

Abrori, H. (2018). Humas Sebagai Method of Commucation Dalam Membentuk Image Madrasah. Al-Tanzim: Jurnal Manajemen Pendidikan Islam, 2(2), 161-166. https://doi.org/10.33650/al-tanzim.v2i2.397

Ardhoyo, T. E. (2013). Peran dan Strategi Humas (Public Relations) dalam Mempromosikan Produk Perusahaan. Jurnal Ilmiah WIDYA, 1(1), 15-21.

Arikunto, S. (2013). Manajemen Penelitian. Jakarta: Rineka Cipta.

Arumsari, N. R. (2017). Penerapan Planning, Organizing, Actuating, Dan Controlling di UPTD Dikpora Kecamatan Jepara. Jurnal Ekonomi Dan Bisnis Kontemporer, 3(2), 1-7.

Awaluddin, H. (2018). Fungsi Manajemen Dalam Pengadaan Infrastruktur Pertanian Masyarakat Di Desa Watatu Kecamatan Banawa Selatan Kabupaten Donggala. Publication, 2(1), 1-12.

Bakri Yusuf, H. R. (2018). Manajemen Komunikasi dalam Pengelolaan Informasi Pembangunan Daerah. Jurnal Komunikasi Hasil Pemikiran Dan Penelitian, 4(1), 50-64.

Cangara, H. (2002). Pengantar Ilmu Komunikai. Jakarta: Raja Grafindo Persada.

Darmastuti, R. (2012). Media Relations - Konsep, Strategi dan Aplikasi. Yogyakarta: CV. Andi Offset.

Depag. (2000). Al-Qur'an dan Terjemahannya. Jakarta: Departemen Agama.

Haryanto, R., \& Rozza, S. (2012). Pengembangan Strategi Pemasaran Dan Manajemen Hubungan Masyarakat Dalam Meningkatkan Peminat Layanan Pendidikan. Jurnal Ekonomi Dan Bisnis, 11(1), 27-34.

Ishak, A. (2012). Peran Public Relations dalam Komunikasi Organisasi. Jurnal Komunikasi, 1(4), 373-380.

Jailani. (2018). Kerangka Kerja Manajemen Humas Dalam Lembaga Pendidikan. Al-Tanzim: Jurnal Manajemen Pendidikan Islam, 2(1), 49-63. https://doi.org/10.33650/al-tanzim.v2i1.248 
Jefkins, F. dan Y. (2003). Public Relations (Kelima). Jakarta: Erlangga.

Kasali, R. (2003). Manajemen Public Relations (Konsep dan Aplikasinya di Indonesia). Jakarta: Pustaka Utama Grafiti.

Krisna Mulawarman, Y. R. (2018). Komunikasi Organisasi pada Dinas Perijinan Kota Yogyakarta untuk Meningkatkan Pelayanan. Jurnal Makna, 5(1), 3141.

Kurnia, N. (2005). Perkembangan Teknologi Komunikasi dan Media Baru: Implikasi terhadap Teori Komunikasi. Jurnal Mediator, 6(2), 291-296.

Linggar, A. M. (2001). Teori dan profesi Kehumasan. Jakarta: Bumi Aksara.

Mahfuzhah, H., \& Anshari, A. (2018). Media Publikasi Humas Dalam Pendidikan. Al-Tanzim: Jurnal Manajemen Pendidikan Islam, 2(2), 137-149. https:// doi.org/10.33650/al-tanzim.v2i2.395

Morisan. (2008). Manajemen Publik Relations. Jakarta: Kencana Prenada Media Group.

Morissan. (2014). Teori Komunikasi Individu Hingga Massa. Jakarta: Kencana Prenadamedia Group.

Mulyono. (2009). Manajemen Administrasi \& Organisasi Pendidikan. Jogjakarta: Ar-Ruzz Media.

Musyarrofah, M. (2018). Peran Humas dalam Pengembangan Pendidikan Tinggi. Jurnal Idaarah, 2(1), 11-23.

Putra, I. G. N. (1999). Manajemen Hubungan Masyarakat. Yogyakarta: Univesitas Atmajaya.

Rachmadi, F. (1996). Public Relations dalam Teori dan Praktik. Jakarta: Gramedia Pustaka Utama.

Rini, K. S. (2017). Peran Humas Dalam Meningkatkan Citra Universitas Tribhuwana Tunggadewi. Ilmu Sosial Dan Ilmu Politik, 1(6.1), 34-37.

Ruslan, R. (2008). Manajemen Public Relations \& MediaKomunikasi. Jakarta: Rajawali Pres.

Sagala, H. S. (2000). Administrasi Pendidikan Kontemporer. Bandung: Alfabeta.

Saleh, A. M. (2008). Manajemen Humas Pemerintah dalam Mendukung Pelaksanaan Program Otonomi Daerah. Administrasi Publik Dan Pembangunan, 2(5), 35-47.

Soemirat, Soleh \& Ardianto, E. (2002). Dasar-Dasar Public Relations. Bandung: PT Remaja Rosdakarya.

Sutikno, M. S. (2012). Manajemen Pendidikan Langkah Praktis Mewujudkan Lembaga Pendidikan Yang Unggul (Tinjaun Umum Dan Islami). Lombok: Holistica.

Usman, H. (2009). Manajemen: Teori Praktek dan Riset Pendidikan. Jakarta: Bumi Aksara. 